\title{
下顎骨骨折の治療成績
}

\author{
重見 英男・黒野 祐一 \\ 渡邊 徳武・茂木 五郎
}

\section{Treatment of Mandibular Fractures}

\author{
Hideo Shigemi, Yuichi Kurono, Noritake Watanabe and Goro Mogi \\ (Oita Medical University)
}

Twelve patients with mandibular fractures were treated with open reduction. Four patients with condylar fracture were treated by excision of the fractured segments which disturbed jaw movement. Patients without the condylar fracture were treated by transosseous wire and/or miniplate fixation. Intermaxillary fixation with an arch bar was also employed to obtain better postoperative occlusion in 8 patients with multiple fractures. However, for monofractures, the wire and miniplate fixation provides firm interosseous fixation and stable occlusion, so intermaxillary fixation with an arch bar is not necessary. In all 12 patients, good postoperative occlusion was acquired within 3 months after surgery.

Key words: mandibular fracture, condylar fracture, intermaxillary fixation

\section{はじめに}

下顎骨骨折は, 複雑な顎関節の機能・形態に 直接影響する骨折であり，その治療は観血的整 復あるいは保存的整復が行われて括り，いずれ の治療方法を選択するかは, 未だ議論の多いと ころである。殊に関節突起骨折の扱いについて は，術者により意見が別れるところである.我 我は，下顎骨骨折の治療を観血的整復で行い， 特に関節突起の関節内骨折は遊離骨片の摘出を 行い, 術後の顎運動・咬合とも良好な結果を得 ている.そこで過去 12 年間に, 当科で手術した 下顎骨骨折12症例について治療方法を検討した。

\section{対象症例}

対象は1981年から1992年までに当科にて入院 手術を行った下顎骨骨折症例12例である．男性 11例, 女性 1 例と圧倒的に男性に多くみられ,
受傷時年齢は $17 \sim 77$ 歳(平均39歳)であった. 受 傷から手術までの期間は最短 1 日, 最長 24 日に わたり, 平均 8 日であった。受傷機転は交通外 傷 7 例, 転倒・転落 5 例であり，これら12例全 例に開口障害・咬合不全がみられた. 12例中 7 例では上顎・煩骨あるいは眼窩底骨折など他部 位の骨折を合併して扣り，下顎骨の久の骨折は 5 例であった. 下顎骨の単骨折は 6 例で, 残り 6 例では，下顎骨に複数の骨折線を認めた。骨 折の分布は表 1 に示すように体部, 筋突起扣よ び関節突起が各々 5 骨折と最も多くみられ, つ いで角部に 3 骨折, 癒合部に 2 骨折で, 上行枝 骨折はなかった。関節突起骨折は 4 例 5 骨折で, 万ち関節内骨折は 3 骨折, 関節外骨折は 2 骨折 であった． 1 例では両側に関節内・外の骨折が みられた。 
従来，下顎骨骨折の観血的整復には鋼線牽引 による固定が行われてきたが，1988年以降の症 例は骨折の固定をより強固なものにするために 主にミニプレートを使用している.

\section{結果}

\section{1. 関節突起以外の骨折治療}

関節突起を除くオトガイ部，体部，ならびに 角部の骨折では，下顎骨下縁に沿う皮膚切開に より骨折部位を骨膜下に露出し，骨折間の肉芽 組織を除去したのち，転位した骨折を整復し，

ミニ・プレートによる強固な固定を行った。ま た剥離骨折など骨折片の転位や咬合不全が軽度 のものでは, ワイヤー固定やフィブリン糊によ る接着固定を行った。

アーチバーによる顎間固定は, 整復・固定の 及では歯牙の欠損や高度な骨折片の転位が原因 で，十分な咬合調節が得られない場合や，複数 の骨折線があり十分な咬合が得られない場合に 行い(図 1 ), 整復・固定のみで良好な咬合が得 られる単骨折症例では, 術後早期に顎運動, 咀 嚼運動を実施するために枵間固定は行わず，チ ンキャップによる外固定を施行した(図 2).

2 . 関節突起の骨折治療

関節突起骨折 5 骨折の弓ち関節包内の座減骨 折 3 例では, 耳前部切開により関節包を露出し
内腔の遊離骨片を摘出した(図 3 )。ささらに, 関 節包内の骨折断端はバーで表面を滑らかにした。 一方, 関節包外の骨折 2 例は, 術後 1 力月間に わたりアーチバーと輪ゴムによる顎間固定を行 った(図 4 ). 顎間固定の除去後は, 開口補助器

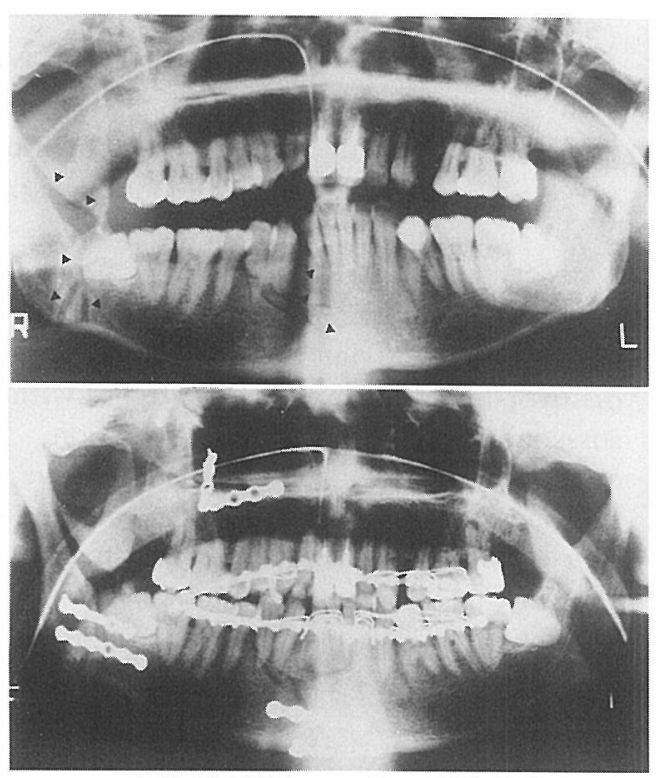

図 1 右下顎角部, 㾑合部の骨折を整復しミニプ レートで固定したのち，アーチバーを用い て顎間固定した。

表 1 下颉買骨骨折部位

\begin{tabular}{|c|c|c|c|c|c|c|c|}
\hline 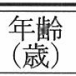 & 性別 & 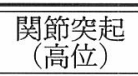 & 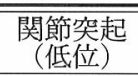 & 筋突起 & 角 部 & 体 部 & 癒合部 \\
\hline 56 & 男 & & & 0 & & & \\
\hline 18 & 男 & & & & 0 & & \\
\hline 42 & 男 & & & 0 & & & \\
\hline 56 & 男 & 0 & & 0 & & 0 & \\
\hline 33 & 男 & & & & 0 & & \\
\hline 17 & 男 & & & & & (a) & \\
\hline 21 & 男 & & & & & 0 & \\
\hline 77 & 女 & 0 & & & & & \\
\hline 28 & 男 & 0 & 0 & & & & 0 \\
\hline 40 & 男 & & 0 & 0 & & & \\
\hline 39 & 男 & & & 0 & 0 & & 0 \\
\hline 42 & 男 & & & & & 0 & \\
\hline
\end{tabular}

$\bigcirc:$ 片側 (O) : 両側 

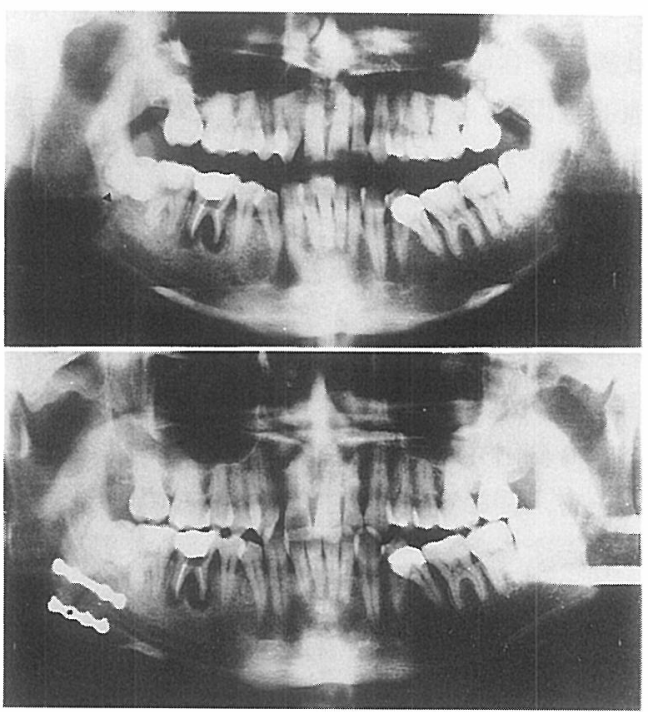

図 2 下顎角部の単骨折は，プレートの固定のみ で良好な咬合が回復でき，アーチバーによ る顎間固定は行わなかった.

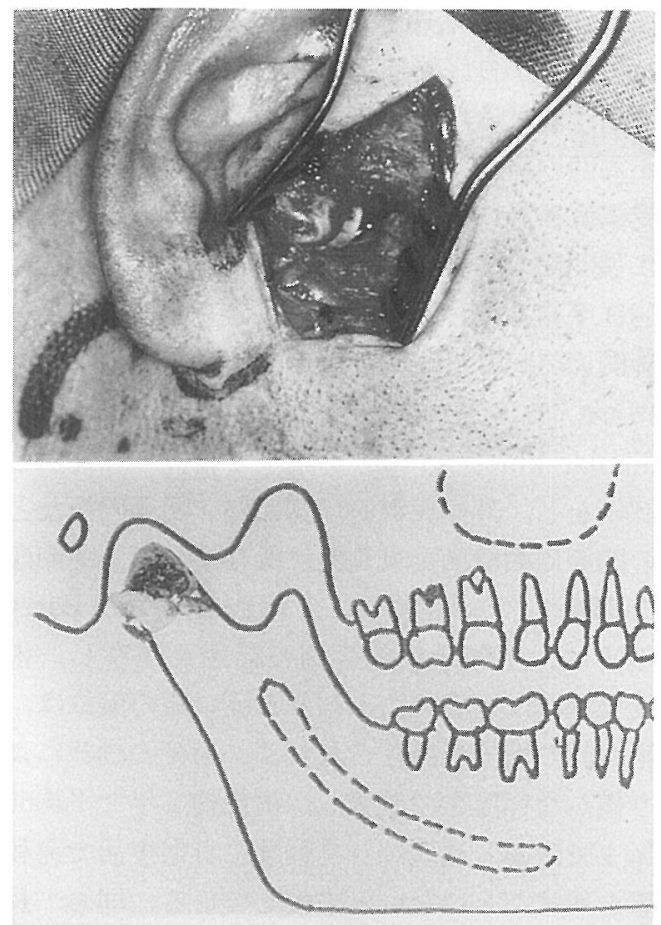

図 3 関節内骨折は耳前部切開にて関節包を開放 し(上段)，遊離骨片を摘出除去した.
を用いて開口訓練を行い, 術後 3 カ月で全症例 とも 3 横指以上の開口が可能となり，満足でき る顎運動・咬合が得られた。

\section{考察}

下顎骨骨折の多くは，ゴム牽引や徒手で転位 した骨片を整復し顎間固定を行う保存的治療が 行われてきた.これは観血的整復法の手技の煩 雑さや，手術侵襲による関節包や神経組織の損 傷が問題視されることと，顎関節は他の関節と 比較して，荷重が少ない関節であり，保存的整 復でも良好な結果が期待できるためであろ $5^{1) \sim 3)}$. しかし，保存的治療のみでは関節頭の 変形や長期の顎間固定が原因となる顎強直や顎 関節症を来たす心配があり，保存的治療，手術 治療のいずれを選択するかは個々の症例により 判断しなければならない。

手術時のアプローチ法は, 骨折線が角部, 体 部，あるいはオトガイ部にある場合には，口腔 内切開と下顎骨下縁に沿ら外切開とが用いられ る. 前者は，顔面に皮庵傷痕を残さない利点が ある。しかし，手術創が絶えず睡液にさらされ， 骨折の固定のためのワイヤーやプレートが感染

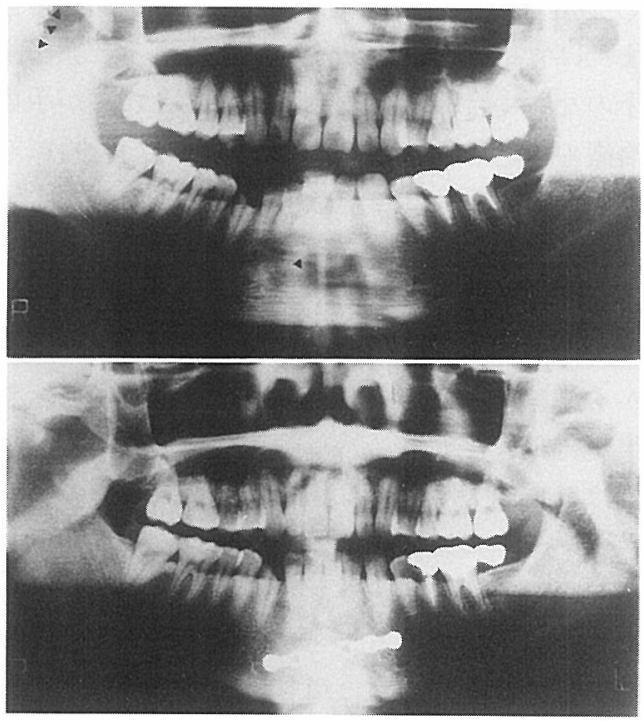

図 4 図 3 の症例であり，術前にみられた関節内 の骨片は除去されている。 
を若起する危険があり，また口腔内切開では， 体部骨折で下歯槽神経が障害となり術野が十分 に展開できず，同様にオトガイ部や角部の骨折 でも粉砕骨折や骨欠損のある骨折，あるいは転 位の大きな症例では，より確実な整復固定が必 要となることからむしろ下顎下縁切開が有利で ある. 下顎下縁切開は, 他の頭頸部手術時に頻 繁に用いるアプローチ法であり, 手術操作時に 顔面神経を損傷する危険もそれほど多くなく， 切開創も丁寧に縫合すれば目立たず有用である. 一方, 関節突起の骨折症例には耳前部切開が必 要となるが，このアプローチも耳下腺手術と汪 ぼ同様であり，手技的な問題は特にない。

観血的手術を行う場合には，顎運動の支点之 なる関節突起が含まれる場合と, 含まれない場 合とで治療方針が異なる4). 関節突起骨折の手 術適応は, (1)両側関節突起の骨折, (2)下顎骨の 他の部位に骨折を伴う場合, (3)脱臼・転位があ り, 受傷後の期間が経過している場合, (4)無歯 顎などで保存的には正常咬合の獲得, および顎 運動の再現, 保持が得られない場合などが挙げ られている. 一方, 関節突起以外の骨折は, (1) 骨折が 1 力所であっても転位が高度である場合, (2)下顎骨の骨折が 2 力所以上の場合, (3)無歯顎, または骨折線の 1 側あるいは対応する上顎に霜 牙のない場合, (4)開放性骨折の場合などが手術 治療の適応とされているが，すべての骨折に対 し手術治療を行うことは可能であり, しかも早 期に良好な術後機能の獲得が得られている.

観血的整復後にアーチバーを用いた顎間固定 を併用する場合が多いが，顎間固定を行うか否 かも議論の多いところである. 手術で十分な整 復が得られた症例, 特に関節突起以外の単骨折 では, 咬筋・咀嚼筋は比較的保たれて沶り, ミ ニプレートで確実な整復が得られれば，アーチ バーを用いずとも，チンキャップのみで良好な 術後機能を回復することが可能である. 特に角 部骨折ではその $79 \%$ は単骨折であると報告され て扣り，その骨折線の多くは後下方に走行し， 転位が少ないことからアーチバーを使用しなく
とも術後機能は良好である5)。 また無歯顎例で は義歯を含めた顎間固定が知られているが，観 血的整復で, ある程度の整復を行えば，後に義 歯を調整することで良好な咬合の回復が期待で き，顎間固定が患者に与える不快感を考慮する と, 必ずしも顎間固定の適応とは考え難い。と ころで，角部，体部などの骨折では，骨折線内 に歯牙が含まれることがあるが，粉砕したり， 歯根の不安定な歯牙は, 後に感染源となる危険 があり摘出されるべきである6).

一方, 関節突起の骨折では, 外側翼突筋をは じめとする咀嚼筋の機能低下により, 顎運動の 障害が起こりやすいが, 縦骨折や粉砕骨折症例 では関節突起の整復に困難を伴らことから保存 的に経過をみる報告が多い，そして顎間固定の みで経過観察した場合でも，受傷初期に拈いて は開口障害が残るものの 2,3 力月で徐々に改 善された症例3) や，小児の顎関節突起骨折に対 して保存的治療を行い, 顎関節運動の良好な回 復を示している報告7)8) もある。しかし，いず れの症例が良好な経過をたどるかは，治療前に 判断することは困難であり, さらに転位の方向 が周囲の筋組織の作用方向と平行な場合には, 受傷直後から著明な顎運動の障害が出現し, 後 に顎関節の強直を引き起こす心配があり, 積極 的に手術治療すべきである，栗田ら ${ }^{9)}$ は，下顎 骨関節突起骨折症例で下顎頭除去を行った症例 について，アンケート，执よび MKG (mandibular kinesiograph) を用いて術後の䫈運動の 評価をし, 外側翼突筋, 関節包, 関節円板など の関節周冊組織を可及的に保存すれば，関節頭 を摘除しても問題ないと報告し，また Barry $ら^{10)}$ は, 下顎頭切除症例の経過を観察し, 術 後早期には全症例にみられた開口路の偏位は, 咀嚼筋の機能が温存されれば, 術後の訓練によ り僅かな程度まで改善し, 術後約 2 年で平均 60 \%まで改善し遺残はごく軽度で日常生活で違和 感を残すことはないと主張している. 即ち, 長 期間の顎間固定を行らよりも，顎関節内の骨折 に対しても他の部位の骨折と同様に手術治療を 
行い, 術後早期に良好な機能を回復するように 努力すべきであると考える。

$$
\text { まとめ }
$$

1）下顎骨骨折12例に観血的手術を行い良好 な術後機能を回復した。

2 ）プレート固定で良好な咬合が得られる症 例では，顎間固定を行わずとも術後機能には問 題がなかった.

3 ）関節内骨折は, 関節内の遊離骨片を除去 し，十分な咬合が回復できた。

\section{参考文献}

1) Gordon $S$ : Interosseous wiring in the treatment of fractures of the mandible. Arch Surg $55: 660 \sim 667,1947$.

2) Schettler D and Rehrmann A : Long-term results function; treatment of condylar fractures with the long bridle according to A. Rehrmann. J Maxillofac Surg 3 : 14 22, 1975.

3）和気不二男, 小野富昭, 前尾安貴子, 他 : 当科 飞扮ける顎顔面骨折飞関する臨床的検討第 2 報 下顎骨骨折の観血的処置症例について. 日外 誌 $35: 1045 \sim 1051,1989$.

4）平 通也, 田嶋定夫：下䋶骨骨折. 耳喉頭頸 61 : 629 634, 1989 .
5) Oikarinen VJ and Malmstrom $\mathrm{M}$ : Fracture lines of the lower jaw. In Archer's Oral and Maxillofacial Surgery, 5th ed. Vol. 1, pp 1053 1056, WB Saunders, Philadelphia, 1975.

6) Guralnic WC : Maxillofacial trauma. Oral Surgery (ed by Hayward JR). pp 164 172, Charles C Thomas Pub, Springfield, 1976.

7) Miller RI and McDonald DK : Remodeling of bilateral condylar fracture in a child. J Oral Maxillofac Surg 44 : 1008 1010, 1986.

8) Heasman PA : Investigation of a 9 year-old condylar neck fracture. Br Dent J $157:$ 396 397, 1984.

9）栗田 浩, 倉科憲治, 小木曽暁, 他：下顎頭除 去後の䫇運動について一下顎骨関節突起骨折 例の検討一. 日口外誌 $36: 2083 \sim 2088,1990$.

10) Barry LE and John JD : Surgical treatment of internal derangements of the temporomandibular joint ; evaluation of two techniques. J Oral Maxillofac Surg 46 : 721 726, 1988.

$$
\left.\begin{array}{l}
\text { 原稿受付 : 平成 } 5 \text { 年 } 5 \text { 月 } 6 \text { 日 } \\
\text { 原稿採択 : 平成 } 5 \text { 年 } 6 \text { 月 } 4 \text { 日 } \\
\text { 別刷請求先 : 重見英男 } \\
\text { T } 879-55 \text { 大分県大分郡㣣間町医大ケ 丘 } 1-1 \\
\text { 大分医科大学耳鼻咽喉科学教室 }
\end{array}\right)
$$

